\title{
ANALISA NILAI SIMPANGAN HORIZONTAL (DRIFT) PADA STRUKTUR TAHAN GEMPA MENGGUNAKAN SISTEM RANGKA BRESING EKSENTRIK TYPE BRACED $V$
}

\author{
Said Jalalul Akbar ${ }^{1)}$, Yovi Chandra' ${ }^{2)}$, Yusriansyah ${ }^{3)}$ \\ Jurusan Teknik Sipil,Universitas Malikussaleh \\ email: jaakidani@gmail.com ${ }^{1)}$,yovicivil@gmail.com ${ }^{2}$
}

DOI: http://dx.doi.org/10.29103/tj.v7i2.139

\begin{abstract}
Abstrak
Negara kepulauan yang berada diwilayah rawan akan gempa salah satunya adalah Indonesia. Hal ini menyebabkan ancaman yang cukup tinggi terhadap bencana gempa. Untuk menahan gempa diperlukan bangunan yang memiliki material serta pengaku (bresing) dengan daktilitas yang cukup. Pada umumnya, bangunan yang terbuat dari material baja dan pengaku (bresing) dengan Sistem Rangka Bresing Eksentrik (SRBE) memiliki sifat daktilitas yang tinggi dan bersifat fleksibel, tidak mudah patah serta cepat dibangun. Tujuan dari penelitian dilakukan untuk membandingkan perubahan drift struktrur baja bangunan gedung tanpa bresing dan gedung yang menggunakan bresing type $\mathrm{V}$ yang diberi beban gravitasi (beban mati dan beban hidup) dan beban horizontal (beban gempa). Model penelitian berupa analisis struktur baja tanpa bresing dan struktur menggunakan bresing type V. Pembebanan gempa dihitung dengan menggunakan analisis dinamik yaitu analisis respon spektrum dan analisis statik ekuivalen. Hasil dari analisis ini menunjukkan bahwa nilai simpangan masing-masing tingkat berdasarkan kinerja batas ultimit telah aman baik struktur tanpa bresing maupun yang menggunakan bresing. Penurunan nilai simpangan yang terjadi antara struktur tanpa bresing dan menggunakan bresing yang terjadi pada arah $X$ yaitu sebesar $51,60 \%$ dan begitupun pada arah Y, penurunan nilai simpangan horizontal yang terjadi yaitu sebesar $44,40 \%$. Hal ini menunjukkan bahwa secara signifikan penggunaan bresing dapat meningkatkan kekakuan, kekuatan dan stabilitas struktur.
\end{abstract}

Kata kunci: simpangan horizontal (drift), kinerja batas ultimit, bresing

\section{Pendahuluan}

Indonesia merupakan negara kepulauan yang berada sangat dekat dengan pertemuan empat lempeng tektonik. Hal ini menyebabkan indonesia mendapatkan ancaman yang cukup tinggi terhadap bencana gempa yang banyak menghancurkan bangunan-bangunan terutama bangunan bertingkat yang tidak mempunyai kekakuan yang memadai. Agar bangunan struktur baja menjadi lebih kaku, maka diberikan pengaku (bresing) pada beberapa bagian dari bangunan tersebut yaitu dengan menggunakan Sistem Rangka Bresing Eksentrik.

SRBE adalah suatu sistem struktur rangka baja tahan gempa yang mempunyai kekakuan elastik yang sangat baik (excellent elastic stiffness). Elemen yang sangat penting dalam mendesain EBF adalah bagian yang terletak antara joint pengaku diagonal dengan joint kolom atau balok yang disebut dengan link beam. Alasan penambahan bresing pada struktur bangunan untuk menambah

Analisa Nilai Simpangan Horizontal (Drift) Pada Struktur Tahan Gempa Menggunakan Sistem Rangka Bresing Eksentrik Type Braced V - Said Jalalul Akbar, Yovi Chandra, Yusriansyah 
kekuatan dan kekakuan struktur sehingga secara efektif dapat mengurangi drift dan menahan deformasi pada suatu bangunan tinggi.

Penelitian ini menganalisis besarnya drift (simpangan) yang terjadi terhadap suatu gedung konstruksi baja tanpa bresing dengan gedung yang sama yang telah dipasang bresing dengan dimensi dan kualitas beton tertentu. Serta membandingkan besar pengaruh penggunaan gedung konstruksi baja tanpa bresing dan menggunakan bresing. Penelitian ini menggunakan jenis bresing tipe $\mathrm{V}$ dengan pendetailan sesuai dengan Standar National Indonesia (SNI) dengan menganalisis dan memodelkan struktur menggunakan software ETABS v9.7.2 dengan struktur dirancang pada wilayah 5 yaitu wilayah Nanggroe Aceh Darussalem (NAD).

\section{Tinjauan Kepustakaan}

\subsection{Dasar Teori}

Menurut Schodek (1999), Gempa bumi terjadi karena fenomena getaran dengan kejutan pada kerak bumi. Faktor utama adalah benturan pergesekan kerak bumi yang mempengaruhi permukaan bumi. Gempa bumi ini menjalar dalam bentuk gelombang. Gelombang ini mempunyai suatu energi yang dapat menyebabkan permukaan bumi dan bangunan di atasnya menjadi bergetar. Getaran ini nantinya akan menimbulkan gaya-gaya pada struktur karena struktur cenderung mempunyai gaya untuk mempertahankan dirinya dari gerakan.

Menurut Schueller (1998), Suatu struktur bangunan akan dikenakan gaya alamiah (geofisik) dan gaya akibat buatan manusia. Gaya-gaya geofisik terjadi karena adanya perubahan dari alam misalnya gaya gravitasi, meteorologi dan seismologi. Sedangkan gaya-gaya buatan manusia berasal dari aktivitas manusia misalnya : kendaraan bermotor, pergerakan manusia dan barang. Baik gaya dari alam maupun buatan manusia akan berpengaruh pada kestabilan struktur, kekuatan struktur. Gaya seismologi sangat berpengaruh pada struktur, apabila struktur mendapat gaya seismologi yang besar maka akan terjadi simpangan horisontal (drift) yang besar pula yang dapat menyebabkan keruntuhan struktur, sehingga diperlukan cara untuk mengatasi hal tersebut.

Menurut Cormak (1995), Gaya lateral pada struktur bangunan harus dipertimbangkan sama seperti gaya gravitasi. Gaya lateral dapat berupa tekanan angin atau gempa dari samping bangunan yang dapat menimbulkan defleksi lateral. Hal yang perlu diperhatikan adalah kekuatan bangunan yang memadai untuk memberikan kenyamanan bagi penghuninya terutama lantai atas. Semakin tinggi gedung defleksi lateral yang terjadi juga semakin besar pada lantai atas. Menurut Becker (1996), Sistem bresing eksentis merupakan struktur portal baja penahan gaya lateral yang merupakan perpaduan dari 2 sistem portal konvensional, yaitu Momen Resisting Frame (MRF) dan Concentrilly Braced Frames (CBF). Sistem ini mempunyai 3 tipe bentuk bresing, yaitu Braced - V, Braced - D dan Braced - Split K.

Menurut Schodek (1999), Dalam merancang suatu struktur bangunan harus diperhatikan kekakuan, kestabilan struktur dalam menahan segala pembebanan yang dikenakan padanya, bagaimana perilaku struktur untuk menahan beban tersebut. Pada struktur stabil apabila dikenakan beban, struktur tersebut akan

Analisa Nilai Simpangan Horizontal (Drift) Pada Struktur Tahan Gempa Menggunakan Sistem Rangka Bresing Eksentrik Type Braced V - Said Jalalul Akbar, Yovi Chandra, Yusriansyah 
mengalami perubahan bentuk (deformasi) yang lebih kecil dibandingkan struktur yang tidak stabil. Hal ini disebabkan karena pada struktur yang stabil memiliki kekuatan dan kestabilan dalam menahan beban. Struktur stabil ini misalnya struktur dengan bresing.

\subsection{Sistem Rangka Bresing Eksentrik (SRBE)}

Menurut SNI Baja 03-1726-2002 pasal 15.13.1, Pada SRBE ada suatu bagian dari balok yang disebut Link dan direncanakan secara khusus. SRBE diharapkan dapat mengalami deformasi inelastis yang cukup besar pada Link saat memikul gaya-gaya akibat beban gempa rencana. Jenis link berdasarkan panjangnya dapat dibedakan menjadi empat kelompok,yaitu:

a) $\mathrm{e} \leq 1,6 \mathrm{Mp} / \mathrm{Vp}$ ( link geser murni )

jenis link ini leleh akibat gaya geser pada respon/deformasi inelastik

b) 1,6 Mp / Vp < e <2,6 Mp / Vp ( link dominan geser )

Jenis link ini leleh akibat dominsasi geser ( pada kombinasi geser dan lentur pada respon/ deformasi inelastik.

c) 2,6 Mp / Vp < e $<5 \mathrm{Mp} / \mathrm{Vp}$ ( link dominan lentur )

Jenis link ini leleh akibat dominasi lentur (pada kombinasi geser dan lentur)

Pada respon/ deformasi inelastik.

d) $\mathrm{e} \geq 5 \mathrm{Mp} / \mathrm{Vp}$ (link lentur murni)

jenis link ini leleh akibat gaya lentur pada respon/deformasi inelastik.

Adapun bentuk-bentuk konfigurasi sistem portal EBF diperlihatkan pada Gambar 1.
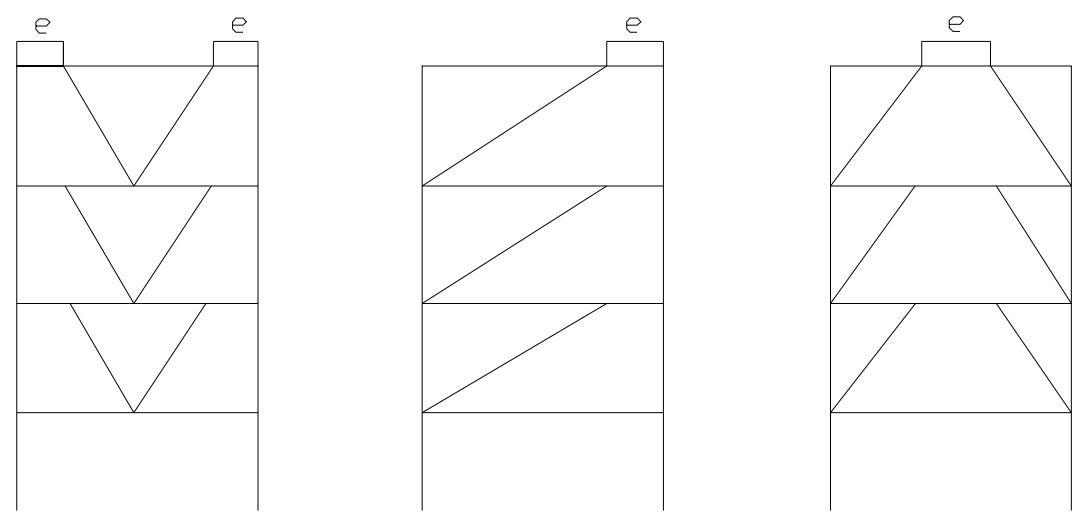

Gambar 1 Konfigurasi Sistem Rangka Bresing Eksentrik (EBF)

Sumber: A. Rengganis, 2012

\subsection{Pembebanan}

Sering kali beban yang terjadi diluar dugaan sehingga diperlukan adanya pendekatan dengan asumsi mendekati beban yang sebenarnya. Beberapa jenis beban yang digunakan dalam bangunan gedung meliputi beban gravitasi dan beban akibat gaya luar yaitu:

Analisa Nilai Simpangan Horizontal (Drift) Pada Struktur Tahan Gempa Menggunakan Sistem Rangka Bresing Eksentrik Type Braced V - Said Jalalul Akbar, Yovi Chandra, Yusriansyah 
A. Beban Gravitasi meliputi :

1. Sesuai SNI 03-1727-2013 pasal 3.1.1, Beban mati adalah berat seluruh bahan konstruksi bangunan gedung yang terpasang, termasuk dinding, lantai, atap, plafon, tangga, dinding partisi tetap, finishing,klading gedung dan komponen arsitektural dan struktural lainnya serta peralatan layan terpasang lain termasuk berat keran.

2. Beban hidup adalah Besarnya beban pada suatu bangunan dapat berubahubah, tergantung pada fungsi bangunan tersebut.

B. Beban Akibat Gaya Luar Meliputi :

1. Beban angin adalah semua beban yang bekerja pada gedung atau bagian gedung yang disebabkan oleh selisih dalam tekanan udara.

2. Pembebanan gempa mengacu pada peraturan pembebanan gempa SNI 031726-2012 tentang Tata Cara Perencanaan Ketahanan Gempa untuk Bangunan Gedung. Analisis beban gempa yang dilakukan adalah analisis beban gempa dinamik dengan menggunakan analisis spectrum respon.

\subsection{Analisis Spektrum Respons Ragam}

Sesuai SNI 03-1726-2012 pasal 7.9, Analisis ragam spektrum respons yaitu suatu cara analisis untuk menentukan respons dinamik struktur gedung yang berperilaku elastik penuh terhadap pengaruh suatu gempa melalui suatu metoda analisis yang dikenal dengan analisis ragam spektrum respons, dimana respons dinamik total struktur gedung tersebut didapat sebagai superposisi dari respons dinamik maksimum masing - masing ragamnya yang didapat melalui spektrum respons gempa rencana.

\subsection{Penentuan Simpangan Antar Tingkat (Drift)}

Menurut SNI 03-1726-2012 pasal 7.8.6, Penentuan simpangan antar lantai tingkat desain $(\Delta)$ harus dihitung sebagai perbedaan defleksi pada pusat massa di tingkat teratas dan terbawah yang ditinjau. Defleksi pusat massa ditingkat $\mathrm{x}\left(\delta_{\mathrm{x}}\right)$ $(\mathrm{mm})$ harus ditentukan sesuai dengan persamaan berikut:

$$
\delta_{x}=\frac{C_{d} x \delta_{x e}}{I_{e}}
$$

Keterangan:

$\mathrm{C}_{\mathrm{d}}=$ faktor amplifikasi defleksi dalam (Tabel 9)

$\delta_{\mathrm{xe}}=$ defleksi pada lokasi yang disyaratkan pada pasal ini yang ditentukan dengan analisis elastis

$\mathrm{I}_{\mathrm{e}} \quad$ = faktor keutamaan gempa yang ditentukan sesuai dengan pasal 4.1.2

\subsection{Kinerja Batas Ultimit}

Menurut SNI 03-1726-2012 Pasal 7.12.1. Syarat kinerja batas ultimit struktur gedung ditentukan simpangan antar tingkat akibat pengaruh gempa rencana dalam kondisi struktur gedung diambang keruntuhan yaitu untuk membatasi kemungkinan terjadinya keruntuhan struktur gedung yang dapat menimbulkan korban jiwa manusia dan untuk mencegah benturan berbahaya antar 
gedung atau antar bagian struktur gedung yang dipisah dengan selat pemisah (delatasi). Untuk dalam segala hal simpangan antar tingkat yang dihitung dari simpangan struktur tidak melampaui simpangan antar tingkat ijin $\left(\Delta_{\mathrm{a}}\right)$ seperti didapatkan dari Tabel 1.

Tabel 1. Simpangan Antar Lantai Ijin, $\Delta_{\mathrm{a}}{ }^{\text {a.b }}$

\begin{tabular}{|l|c|c|c|}
\hline \multirow{2}{*}{ Struktur } & \multicolumn{2}{|c|}{ Kategori Risiko } \\
\cline { 2 - 4 } & I atau II & III & IV \\
\hline $\begin{array}{l}\text { Struktur, selain dari struktur dinding geser } \\
\text { batu bata, 4 tingkat atau kurang dengan } \\
\text { dinding interior, partisi, langit-langit dan } \\
\text { sistem dinding eksterior yang telah } \\
\text { didesain untuk mengakomodasi simpangan } \\
\text { antar lantai tingkat. }\end{array}$ & $0,025 \mathrm{~h}_{\mathrm{sx}}{ }^{\mathrm{e}}$ & $0,020 \mathrm{~h}_{\mathrm{sx}}^{\mathrm{e}}$ & $0,015 \mathrm{~h}_{\mathrm{sx}}{ }^{\mathrm{e}}$ \\
\hline $\begin{array}{l}\text { Struktur dinding geser kantilever batu } \\
\text { bata }\end{array}$ & $0,010 \mathrm{~h}_{\mathrm{sx}}{ }^{\mathrm{e}}$ & $0,010 \mathrm{~h}_{\mathrm{sx}}{ }^{\mathrm{e}}$ & $0,010 \mathrm{~h}_{\mathrm{sx}}{ }^{\mathrm{e}}$ \\
\hline Struktur dinding geser batu bata lainnya & $0,007 \mathrm{~h}_{\mathrm{sx}}{ }^{\mathrm{e}}$ & $0,007 \mathrm{~h}_{\mathrm{sx}}{ }^{\mathrm{e}}$ & $0,007 \mathrm{~h}_{\mathrm{sx}}$ \\
\hline Semua struktur lainnya & $0,020 \mathrm{~h}_{\mathrm{sx}}{ }^{\mathrm{e}}$ & $0,015 \mathrm{~h}_{\mathrm{sx}}{ }^{\mathrm{e}}$ & $0,010 \mathrm{~h}_{\mathrm{sx}}{ }^{\mathrm{e}}$ \\
\hline
\end{tabular}

Sumber: SNI 03-1726-2012

Keterangan :

- $\mathrm{h}_{\mathrm{sx}}$ adalah tinggi tingkat dibawah tingkat yang bersangkutan.

- Untuk sistem penahan gaya gempa yang terdiri dari hanya rangka momen dalam kategori desain seismik D,E, dan F simpangan antar lantai tingkat ijin harus sesuai dengan persayaratan $\Delta_{\mathrm{a}} / \rho$ ( Faktor redundansi ).

\subsection{Program ETABS v9.7.2}

Menurut Haryanto (2006), Program ETABS (Extended 3D Analysis of Building Systems) adalah program komputer yang digunakan khusus untuk analisis dan disain bangunan gedung.

\section{Permodelan Struktur}

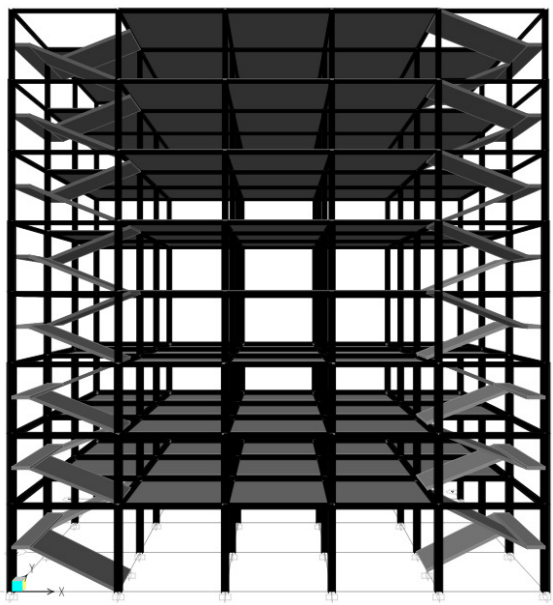

a. Stuktur Menggunakan Bresing V

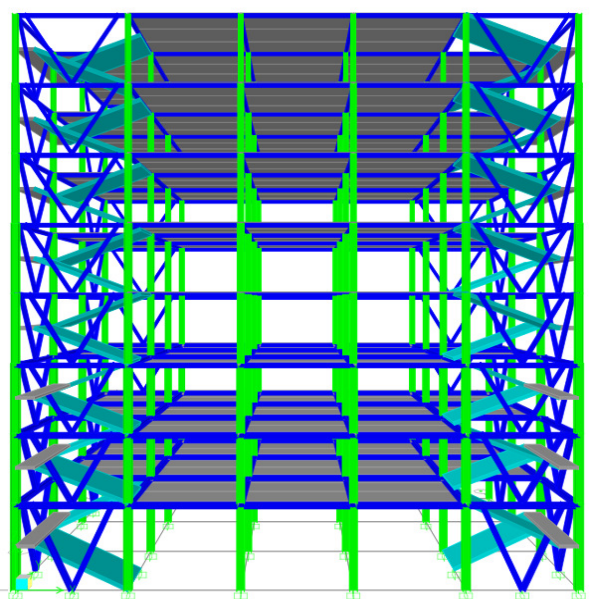

b. Struktur Tanpa Bresing

Gambar 2 Pemodelan Struktur

Analisa Nilai Simpangan Horizontal (Drift) Pada Struktur Tahan Gempa Menggunakan Sistem Rangka Bresing Eksentrik Type Braced V - Said Jalalul Akbar, Yovi Chandra, Yusriansyah 

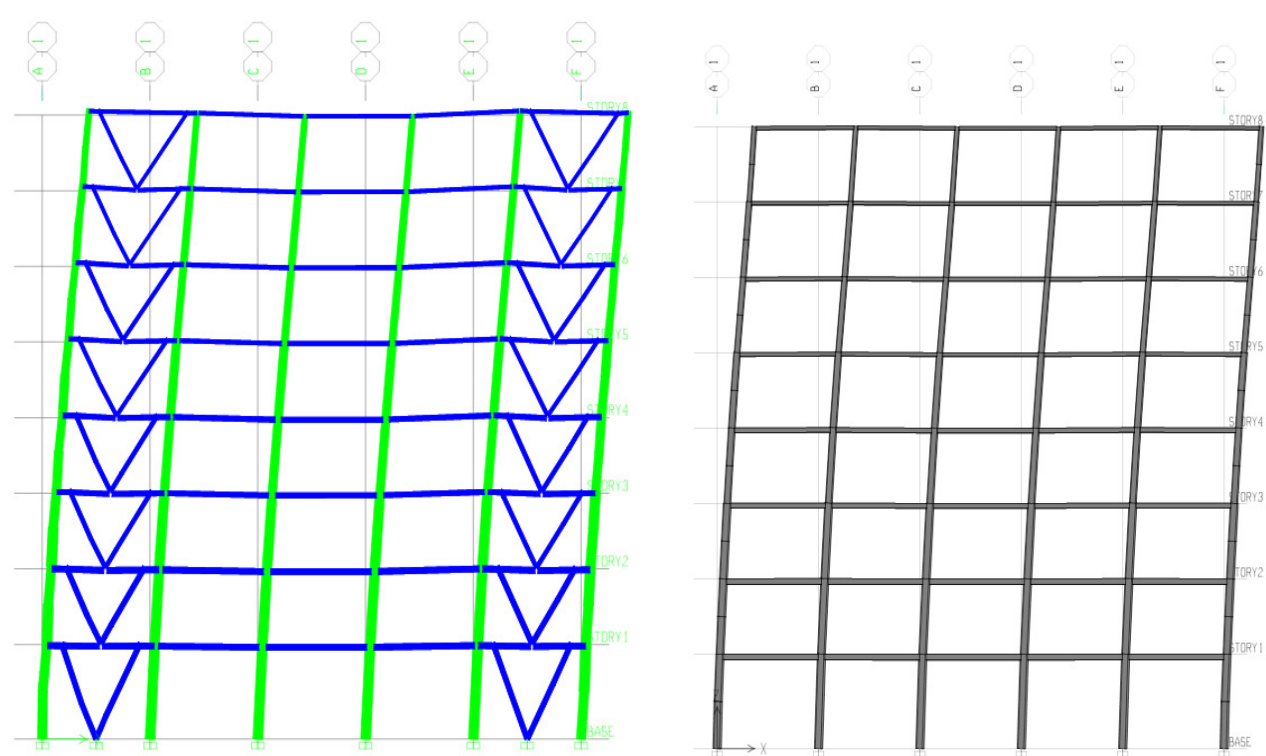

Gambar 3 (a): Permodelan simpangan yang terjadi pada struktur menggunakan bresing $\mathrm{V}$.

(b): Permodelan Simpangan yang terjadi pada struktur tanpa bresing

\section{Metode Penelitian}

\subsection{Geometri Struktur}

Model gedung yang akan dianalisis berupa struktur tanpa bresing dan menggunakan bresing dengan Sistem Rangka Bresing Eksentrik (SRBE) Type Braced $V$ dengan gedung 8 lantai termasuk atap. Ukuran denah $18 \mathrm{~m} \times 30 \mathrm{~m}$. Ketinggian lantai paling bawah yaitu $5 \mathrm{~m}$, selanjutnya tipikal dengan ketinggian yaitu $4 \mathrm{~m}$. Jarak antar kolom yaitu $6 \mathrm{~m}$. fungsi gedung digunakan sebagai perkantoran.

\subsection{Material Struktur} berikut:

Material baja yang digunakan yaitu jenis BJ 37 dengan spesifikasi sebagai
a. Jenis Baja
: BJ 37
b. Tegangan leleh baja, Fy
: $240 \mathrm{Mpa}$
c. Tegangan Ultimate baja, $\mathrm{Fu}$
: $370 \mathrm{Mpa}$
d. Berat Jenis Baja
$: 7850 \mathrm{~kg} / \mathrm{m}^{3}$

\subsection{Pendimensian Elemen Struktur}

Profil baja penampang yang digunakan pada struktur tanpa bresing dan menggunakan bresing adalah sama, kecuali adanya penambahan elemen bresing pada SRBE. Profil baja yang digunakan pada kedua struktur adalah sebagai berikut:

\section{Kolom}

- Lantai Dasar (Base) : IWF 400 x 400 × 21 x 13

- Lantai $1 \& 2$ : IWF 400 x $400 \times 21$ x 13

Analisa Nilai Simpangan Horizontal (Drift) Pada Struktur Tahan Gempa Menggunakan Sistem Rangka Bresing Eksentrik Type Braced V - Said Jalalul Akbar, Yovi Chandra, Yusriansyah 
- Lantai $3 \& 4$

- Lantai 5 \& 6

- Lantai 7 \& 8

Balok

- Lantai 1 \& 2

- Lantai 3 \& 4

- Lantai 5 \& 6

- Lantai 7 \& 8

Bresing

- Lantai Base

- Lantai 1 \& 2

- Lantai 3 \& 4

- Lantai 5 \& 6

- Lantai 7 \& 8
: IWF $350 \times 350 \times 19 \times 12$

: IWF $300 \times 300 \times 15 \times 10$

: IWF $250 \times 250 \times 14 \times 9$

: IWF $300 \times 300 \times 15 \times 10$

: IWF $250 \times 250 \times 14 \times 9$

: IWF $200 \times 200 \times 12 \times 8$

: IWF 175 x 175 x $11 \times 7,5$

: IWF $250 \times 250 \times 14 \times 14$

: IWF $250 \times 250 \times 14 \times 14$

: IWF $200 \times 200 \times 16 \times 10$

: IWF $175 \times 175 \times 12 \times 10$

: IWF $150 \times 150 \times 10 \times 7$

\subsection{Kriteria Perencanaan}

Asumsi-asumsi desain yang digunakan pada pemodelan dan perencanaan struktur adalah sebagai berikut:

* Pemodelan Struktur dilakukan secara frame and shell element menggunakan software ETABS v9.7.2

* Plat lantai digunakan metal deck dengan tebal plat sebesar $150 \mathrm{~mm}$

* Pondasi dianggap jepit

* Zona wilayah Terletak pada wilayah 5 yaitu Nanggroe Aceh Darussalam.

* Jenis tanah yang digunakan yaitu tanah keras.

\subsection{Pembebanan Struktur}

Beban yang diperhitungkan untuk desain struktur meliputi beban vertikal (gravitasi) dan beban gempa (Earthquake Load). Beban- beban yang bekerja pada beban vertikal (gravitasi) yaitu terdiri dari beban mati dan beban hidup yang mengacu pada SNI Beban Minimum Untuk Perancangan Bangunan Gedung dan Struktur Lain SNI 03-1727-2013. Beban-beban yang bekerja pada beban gempa menggunakan 2 metode yaitu metode analisis statik ekuivalen dan dinamik respons spectrum yang mengacu pada SNI Tata Cara Perencanaan Ketahanan Gempa untuk Struktur Bangunan Gedung dan Non Gedung SNI 03-1726-2012.

\section{Hasil dan Pembahasan}

\subsection{Kontrol Kinerja Struktur}

Nilai simpangan diambil dari hasil output yang dianalisis menggunaka software ETABS yang nilai tersebut diambil yang terbesar dan paling berpengaruh dengan hasil nilai simpangan sebagai berikut:

A. Struktur Tanpa Bresing

Pada perhitungan ini nilai simpang diambil sesuai SNI-03-1726-2012 Pasal 7.12.1 Syarat kontrol kinerja struktur berdasarkan kinerja batas ultimit ditentukan oleh simpangan. Nilai simpangan diambil dari hasil analisis yang terbesar dan paling berpengaruh yaitu pada EQY untuk arah X dan RSPY 
untuk arah Y struktur gedung dengan faktor-faktor yaitu faktor pembesaran defleksi (Cd) untuk SRPMK adalah 5,5. Faktor keutamaan gempa (Ie) adalah 1, faktor reduksi untuk gedung dengan KDS D adalah 1,3.Simpang antar lantai yang diijinkan untuk gedung dengan kriteria resiko II adalah $\Delta \mathrm{a}=(0,020) \times \mathrm{H}$. Hasil kontrol simpang seperti pada Tabel 2 dan Tabel 3.

Tabel 2 Kontrol Simpangan Struktur Tanpa Bresing Untuk Arah X

\begin{tabular}{|c|c|c|c|c|c|c|}
\hline Lantai & $\begin{array}{c}\mathbf{H} \\
(\mathbf{m m})\end{array}$ & $\begin{array}{c}\text { Drift X } \\
(\mathbf{m m})\end{array}$ & $\begin{array}{c}\boldsymbol{\delta} \\
(\mathbf{m m})\end{array}$ & $\begin{array}{c}\Delta \\
(\mathbf{m m})\end{array}$ & $\begin{array}{c}\Delta \mathbf{a} \\
(\mathbf{m m})\end{array}$ & Ket \\
\hline 8 & 4000 & 88,97 & 489,34 & 62,10 & 80,00 & Aman \\
\hline 7 & 4000 & 77,68 & 427,24 & 70,57 & 80,00 & Aman \\
\hline 6 & 4000 & 64,85 & 356,68 & 76,23 & 80,00 & Aman \\
\hline 5 & 4000 & 50,99 & 280,45 & 69,08 & 80,00 & Aman \\
\hline 4 & 4000 & 38,43 & 211,37 & 64,24 & 80,00 & Aman \\
\hline 3 & 4000 & 26,75 & 147,13 & 54,51 & 80,00 & Aman \\
\hline 2 & 4000 & 16,84 & 92,62 & 46,97 & 80,00 & Aman \\
\hline 1 & 4000 & 8,30 & 45,65 & 45,65 & 100,00 & Aman \\
\hline Base & 5000 & 0,00 & 0,00 & 0,00 & 0 & Aman \\
\hline
\end{tabular}

Tabel 3 Kontrol Simpangan Struktur Tanpa Bresing Untuk Arah Y

\begin{tabular}{|c|c|c|c|c|c|c|}
\hline Lantai & $\begin{array}{c}\mathbf{H} \\
(\mathbf{m m})\end{array}$ & $\begin{array}{c}\text { Drift Y } \\
(\mathbf{m m})\end{array}$ & $\begin{array}{c}\boldsymbol{\delta} \\
(\mathbf{m m})\end{array}$ & $\begin{array}{c}\Delta \\
(\mathbf{m m})\end{array}$ & $\begin{array}{c}\Delta \mathbf{a} \\
(\mathbf{m m})\end{array}$ & Ket \\
\hline 8 & 4000 & 38,30 & 210,65 & 27,56 & 80,00 & Aman \\
\hline 7 & 4000 & 33,29 & 183,10 & 27,72 & 80,00 & Aman \\
\hline 6 & 4000 & 28,25 & 155,38 & 30,14 & 80,00 & Aman \\
\hline 5 & 4000 & 22,77 & 125,24 & 26,84 & 80,00 & Aman \\
\hline 4 & 4000 & 17,89 & 98,40 & 27,56 & 80,00 & Aman \\
\hline 3 & 4000 & 12,88 & 70,84 & 24,15 & 80,00 & Aman \\
\hline 2 & 4000 & 8,49 & 46,70 & 21,84 & 80,00 & Aman \\
\hline 1 & 4000 & 4,52 & 24,86 & 24,86 & 100,00 & Aman \\
\hline Base & 5000 & 0,00 & 0,00 & 0,00 & 0,00 & Aman \\
\hline
\end{tabular}

Hasil pada tabel di atas menunjukkan bahwa kontrol batasan waktu untuk gedung tanpa bresing telah memenuhi persyaratan sesuai dengan yang disyarat (memenuhi/aman). Perhitungan nilai partisipasi massa pada perhitungan sebelumnya juga telah memenuhi persyaratan dengan nilai partisipasi massa melebihi $90 \%$, sedangkan persyaratan minimum $90 \%$.

B. Struktur menggunakan Bresing (SRBE)

Sesuai SNI-03-1726-2012 Pasal 7.12.1 Syarat kontrol kinerja struktur berdasarkan kinerja batas ultimit ditentukan oleh simpangan. Nilai simpangan diambil dari hasil analisis pembebanan gempa yang sama pada struktur tanpa bresing yaitu pada EQY untuk arah X dan RSPY untuk arah Y sebagai perbandingan antara struktur tanpa bresing dan SRBE bresing $\mathrm{V}$ dengan faktor-faktor yaitu faktor pembesaran defleksi (Cd) untuk SRBE adalah 4, 
faktor keutamaan gempa (Ie) adalah 1, faktor reduksi untuk gedung dengan KDS D adalah 1,3 dan simpang antar lantai yang diijinkan untuk gedung dengan kriteria resiko II adalah $\Delta \mathrm{a}=(0,020) \times \mathrm{H}$. Hasil kontrol simpang seperti pada Tabel 4 dan Tabel 5.

Tabel 4 Kontrol Simpangan Struktur Bresing V Untuk Arah X

\begin{tabular}{|c|c|c|c|c|c|c|}
\hline Lantai & $\begin{array}{c}\mathbf{H} \\
(\mathbf{m m})\end{array}$ & $\begin{array}{c}\text { Drift X } \\
(\mathbf{m m})\end{array}$ & $\begin{array}{c}\boldsymbol{\delta} \\
(\mathbf{m m})\end{array}$ & $\begin{array}{c}\Delta \\
(\mathbf{m m})\end{array}$ & $\begin{array}{c}\Delta \mathbf{a} \\
(\mathbf{m m})\end{array}$ & Ket \\
\hline 8 & 4000 & 59,21 & 236,85 & 33,80 & 80,00 & Aman \\
\hline 7 & 4000 & 50,76 & 203,06 & 36,38 & 80,00 & Aman \\
\hline 6 & 4000 & 41,67 & 166,68 & 36,08 & 80,00 & Aman \\
\hline 5 & 4000 & 32,65 & 130,60 & 32,93 & 80,00 & Aman \\
\hline 4 & 4000 & 24,42 & 97,67 & 30,49 & 80,00 & Aman \\
\hline 3 & 4000 & 16,80 & 67,18 & 25,50 & 80,00 & Aman \\
\hline 2 & 4000 & 10,42 & 41,68 & 20,99 & 80,00 & Aman \\
\hline 1 & 4000 & 5,17 & 20,68 & 20,68 & 100,00 & Aman \\
\hline Base & 5000 & 0,00 & 0,00 & 0,00 & 0,00 & Aman \\
\hline
\end{tabular}

Tabel 5 Kontrol Simpangan Struktur Untuk Arah Y

\begin{tabular}{|c|c|c|c|c|c|c|}
\hline Lantai & $\begin{array}{c}\mathbf{H} \\
(\mathbf{m m})\end{array}$ & $\begin{array}{c}\text { Drift Y } \\
(\mathbf{m m})\end{array}$ & $\begin{array}{c}\boldsymbol{\delta} \\
(\mathbf{m m})\end{array}$ & $\begin{array}{c}\Delta \\
(\mathbf{m m})\end{array}$ & $\begin{array}{c}\Delta \mathbf{a} \\
(\mathbf{m m})\end{array}$ & Ket \\
\hline 8 & 4000 & 29,29 & 117,14 & 16,50 & 80,00 & Aman \\
\hline 7 & 4000 & 25,16 & 100,64 & 16,90 & 80,00 & Aman \\
\hline 6 & 4000 & 20,94 & 83,74 & 16,72 & 80,00 & Aman \\
\hline 5 & 4000 & 16,76 & 67,02 & 15,31 & 80,00 & Aman \\
\hline 4 & 4000 & 12,93 & 51,71 & 14,95 & 80,00 & Aman \\
\hline 3 & 4000 & 9,19 & 36,76 & 12,88 & 80,00 & Aman \\
\hline 2 & 4000 & 5,97 & 23,88 & 10,88 & 80,00 & Aman \\
\hline 1 & 4000 & 3,25 & 13,00 & 13,00 & 100,00 & Aman \\
\hline Base & 5000 & 0,00 & 0,00 & 0,00 & 0,00 & Aman \\
\hline
\end{tabular}

Pada tabel di atas juga menunjukkan bahwa kontrol batasan waktu untuk gedung menggunakan bresing telah memenuhi persyaratan yang diijinkan (memenuhi/aman). Dapat dikatakan bahwa Penambahan penopang (bresing) pada struktur gedung dapat mengurangi secara signifikan simpangan tidak melebihi batas ultimit sehingga struktur aman dari keruntuhan struktur dan benturan antar gedung.

\subsection{Penurunan Nilai Simpangan}

Hasil dari analisa dengan menggunakan softwer ETABS 9.0 menunjukkan adanya perubahan simpang struktur sebelum dipasang bresing dan sesudah dipasang bresing V dengan Sistem Rangka Bresing Eksentrik. Perbandingan Perubahan Simpangan Horizontal Sebelum dan Sesudah Pemasangan Bresing V Sistem Rangka Baja Eksentrik dapat dilihat pada Tabel 6. 
Tabel 6 Perbandingan Perubahan Simpangan Horizontal Sebelum dan Sesudah Pemasangan Bresing V Sistem Rangka Baja Eksentrik

\begin{tabular}{|c|c|c|c|c|}
\hline \multirow[b]{2}{*}{$\begin{array}{c}\text { Tingkat } \\
\text { Lantai }\end{array}$} & \multicolumn{2}{|c|}{ Simpangan Arah X (mm) } & \multicolumn{2}{|c|}{ Simpangan Arah Y (mm) } \\
\hline & $\begin{array}{c}\text { Tanpa Bresing } \\
(\mathrm{mm})\end{array}$ & $\begin{array}{c}\text { Bresing V } \\
(\mathrm{mm})\end{array}$ & $\begin{array}{c}\text { Tanpa Bresing } \\
(\mathbf{m m})\end{array}$ & $\begin{array}{c}\text { Bresing V } \\
(\mathbf{m m})\end{array}$ \\
\hline 8 & 62,10 & 33,80 & 27,56 & 16,50 \\
\hline 7 & 70,57 & 36,38 & 27,72 & 16,90 \\
\hline 6 & 76,23 & 36,08 & 30,14 & 16,72 \\
\hline 5 & 69,08 & 32,93 & 26,84 & 15,31 \\
\hline 4 & 64,24 & 30,49 & 27,56 & 14,95 \\
\hline 3 & 54,51 & 25,50 & 24,15 & 12,88 \\
\hline 2 & 46,97 & 20,99 & 21,84 & 10,88 \\
\hline 1 & 45,65 & 20,68 & 24,86 & 13 \\
\hline Base & 0 & 0,00 & 0 & 0 \\
\hline Jumlah & 489,350 & 236,850 & 210,670 & 117,140 \\
\hline Penurunan $(\%)$ & & $51,60 \%$ & & $44,40 \%$ \\
\hline
\end{tabular}

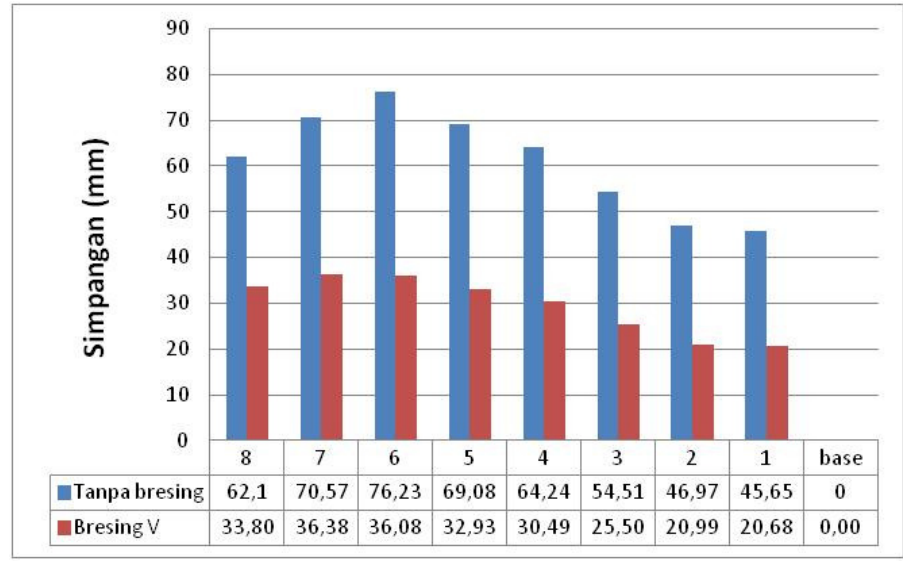

Gambar 4 Grafik Penurunan Simpangan Arah X

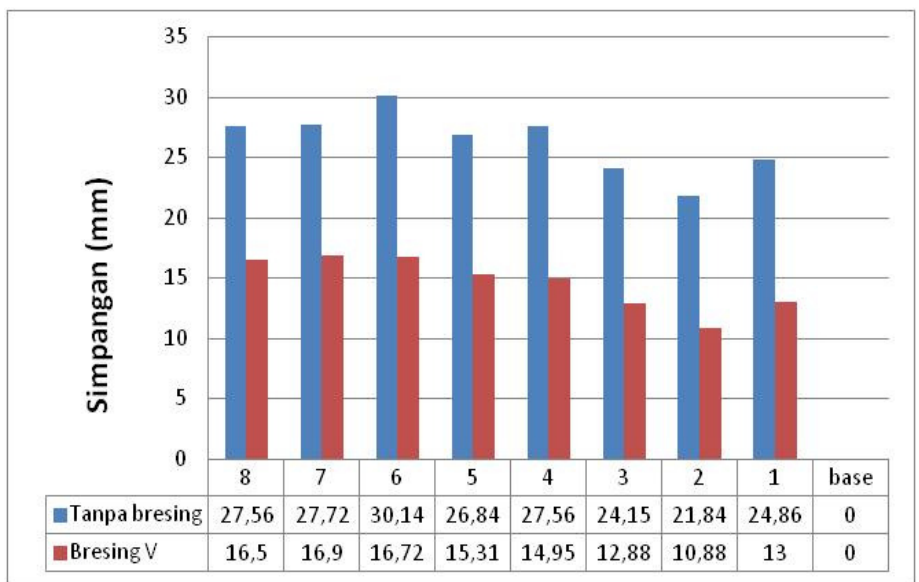

Gambar 5 Grafik Penurunan Simpangan Arah Y

Analisa Nilai Simpangan Horizontal (Drift) Pada Struktur Tahan Gempa Menggunakan Sistem Rangka Bresing Eksentrik Type Braced V - Said Jalalul Akbar, Yovi Chandra, Yusriansyah 
Berdasarkan hasil perhitungan yang telah dilakukan dalam penelitian ini menunjukkan bahwa bresing $\mathrm{V}$ dengan sistem rangka bresing eksentrik (SRBE) dapat mengurangi simpangan horizontal (drift) bila dibandingkan dengan tanpa menggunakan bresing dengan kisaran perbedaannya $51,40 \%$ pada arah $\mathrm{X}$ dan $44,40 \%$ pada arah Y dimana nilai penurunan perbandingan tersebut sangat jauh.

\section{Kesimpulan dan Saran}

\subsection{Kesimpulan}

Berdasarkan analisis hasil dan pembahasan mengenai pengaruh penambahan penopang (bracing) pada struktur gedung konstruksi baja yang diberi beban Gravitasi (beban mati dan beban hidup) dan beban gempa, maka dapat diambil kesimpulan sebagai berikut:

1. Kontrol batasan waktu untuk Gedung tanpa bresing dan gedung yang mengguanakan brasing $\mathrm{V}$ dengan sistem rangka bresing eksentrik (SRBE) telah terpenuhi.

2. Kontrol partisipasi massa untuk gedung tanpa bresing dan menggunakan bresing telah memenuhi persyaratan dengan nilai partisipasi massa melebihi $90 \%$.

3. Penambahan penopang (bracing) pada struktur gedung dapat mengurangi secara signifikan simpangan tidak melebihi batas ultimit sehingga struktur aman dari keruntuhan struktur dan benturan antar gedung.

4. Dapat disimpulkan bahwa bresing V dengan sistem rangka bresing eksentrik (SRBE) dapat mengurangi simpangan horizontal (drift) bila dibandingkan dengan tanpa menggunakan bresing dengan kisaran perbedaannya $51,40 \%$ pada arah X dan $44,40 \%$ pada arah Y dimana nilai penurunan perbandingan tersebut sangat jauh.

\subsection{Saran}

Berdasarkan hasil penelitian, saran yang perlu dikembangkan dalam penelitian ini adalah Perlu dilakukan analisis perbandingan kekakuan struktur gedung menggunakan bresing konsentrik (SRBC) dan bresing eksentrik (SRBE).

Disamping itu juga perlu dianalisis sambungan baik antara balok dengan bracing, kolom dengan bracing dan balok dengan kolom pada struktur gedung tersebut.

Untuk selanjutnya studi bisa dilakukan pada struktur yang memiliki konfigurasi yang tidak simetris untuk bangunan tingkat tinggi.

\section{Daftar Kepustakaan}

Anonim, 2002, SNI 03-1729-2002 Tata Cara Struktur Baja Tahan Gempa Untuk Bangunan Gedung, BSN, Bandung. Anonim, 2012, SNI 03-1729-2012 Tata Cara Perencanaan Ketahanan Gempa Untuk Struktur Bangunan Gedung dan Non Gedung, BSN, Bandung. 
Anonim, 2013, SNI 03-1727-2013 Beban Minimum Untuk Perancangan Bangunan Gedung dan Struktur Lainnya, BSN, Bandung.

Haryanto, Y.M, 2006, Panduan Analisis Dan Desain Struktur Menggunakan ETABS Versi 8.4.5, Universitas Atma Jaya, Yogyakarta.

Rengganis, A, 2012, Studi Perilaku Struktur Eccentrically Braced Frames (DEBF) Dengan Link Pendek Menggunakan RSNI Gempa 03-1726-201x, (Diunduh tanggal 1 September 2015).

Schueller, W, 1989, Struktur Dan Konstruksi Bangunan Tinggi. PT.Eresco. Bandung

Schodek, D L, 1999. Struktur. Edisi kedua, Erlangga, Jakarta 